\title{
Michał KOKOWSKI
}

Instytut Historii Nauki im. L. i A. Birkenmajerów

Polskiej Akademii Nauk

michal.kokowski@gmail.com

\section{SZKIC AKTUALNEJ DEBATY \\ NAD NAUKOMETRIĄ I BIBLIOMETRIĄ W POLSCE I ZAPOMNIANE NAUKOZNAWSTWO}

\begin{abstract}
Streszczenie
W toczonej w Polsce w ostatnich trzech dekadach debacie na temat naukometrii i bibliometrii popełniono bardzo poważny błąd metodyczny: pominięto refleksję naukoznawczą, szczególnie historyczno-metodologiczną. Artykuł rozważa to pominięte zagadnienie.

Aby zrealizować ten cel, posłużono się metodą badań interdyscyplinarnych z zakresu naukoznawstwa i historii naukoznawstwa. Zastosowano tę metodę do analizy wybranych najważniejszych publikacji na temat naukometrii i bibliometrii ostatnich trzech dekad, ze szczególnym uwzględnieniem kontekstu polskiego.

Artykuł omawia: a) kontekst aktualnej debaty na temat naukometrii i bibliometrii w Polsce; b) historię polskich analiz naukometrycznych opartych na zagranicznych bazach indeksacyjnych; c) aktualną dyskusję na temat naukometrii i bibliometrii w Polsce oraz d) pominięty w aktualnej debacie kluczowy aspekt - nierozerwalny związek naukometrii i bibliometrii z naukoznawstwem.

Wnioskiem z przeprowadzonych badań jest postulat powrotu w Polsce do badań informetrycznych (naukometrycznych, bibliometrycznych, webometrycznych, ...), świadomie rozwijanych w kontekście zintegrowanego naukoznawstwa. Wiedzę tę należy wykorzystać w kształtowaniu aktualnej polityki naukowej: struktury organizacyjnej nauki i szkolnictwa wyższego oraz formowania zasad oceny dorobku naukowego instytucji i poszczególnych pracowników oraz czasopism naukowych.

Słowa kluczowe: naukometria, bibliometria, informetria, metodologia naukometrii, nadużycia metod naukometrycznych, naukoznawstwo, polityka naukowa, polskie i międzynarodowe standardy naukometrii
\end{abstract}




\section{Wstęp metodyczny}

W toczonej w Polsce od lat 90. XX wieku debacie na temat naukometrii i bibliometrii uderza brak refleksji naukoznawczej, szczególnie historyczno-metodologicznej. To bardzo poważny błąd metodyczny (co zostanie okazane w niniejszym artykule).

Aby go usunąć, należy świadomie posłużyć się metodą badań interdyscyplinarnych z zakresu naukoznawstwa i historii naukoznawstwa, i konsekwentnie zastosować ją do analizy wybranych najważniejszych publikacji na temat naukometrii i bibliometrii ostatnich dekad, ze szczególnym uwzględnieniem kontekstu polskiego.

Niniejszy artykuł przedstawia wyniki takiej analizy.

\section{Kontekst aktualnej debaty o naukometrii i bibliometrii w Polsce}

Od lat dziewięćdziesiątych ubiegłego wieku toczona jest w Polsce dyskusja na temat oceny pozycji polskich jednostek naukowych w rankingach międzynarodowych i krajowego systemu ewaluacji instytucji naukowych, periodyków naukowych oraz dorobku naukowego badaczy. ${ }^{1}$

Strona rządowa i różne grupy polskich publicystów od wielu lat podnoszą wątek rzekomo bardzo niskiej pozycji polskich uniwersytetów i polskiej nauki w międzynarodowych rankingach. ${ }^{2} \mathrm{~W}$ przypadku ewaluacji uniwersytetów chodzi o odległe pozycje najlepszych dwóch polskich uczelni: Uniwersytetu Jagiellońskiego i Uniwersytetu Warszawskiego - zależnie od rankingu - w co najwyżej trzeciej, czwartej lub piątej setce

1 Zob. np. Vetulani 1990, Jasieński 1991; Stefaniak 1994; Kozłowski 1994; Kozłowski, Kopko 1995; Racki 1996a; Wróblewski 1998a. (Uwaga: Odnośniki dotyczace literatury z zakresu naukometrii - bibliometrii - informetrii podane sq w odrębnej publikacji: Kokowski 2015.)

${ }^{2}$ Między innymi takich jak: Academic Ranking of World Universities, The World University Rankings, QS World University Rankings, Performance Ranking of Scientific Papers for World Universities, Ranking Web of World Universities oraz CWTS Leiden Ranking - zob. odpowiednio: Center for World-Class Universities of Shanghai Jiao Tong University (CWCU) 2015; Times Higher Education 2015; QS Quacquarelli Symonds Limited 2015; Higher Education Evaluation and Accreditation Council of Taiwan 2015; Cybermetrics Lab 2015 oraz CWTS Leiden Ranking 2015.

W niniejszym artykule nie ma miejsca, aby dokonać szczegółowej analizy zasad oceniania przyjętych w poszczególnych rankingach. To temat warty odrębnych badań. Poprzestańmy na generalnej uwadze: niska pozycja polskich uczelni w rankingach międzynarodowych wynika $\mathrm{z}$ błędnego modelu polskiego uniwersytetu: to model preferujący uczelnię z nadmierną liczbą studentów przypadających na jednego pracownika naukowego i małej efektywności naukowej, co z kolei spowodowane jest przeciążeniem nauczycieli akademickich dydaktyką (czyli de facto brakami kadrowymi na uczelni) i niedofinansowaniem nauki. W tej kwestii zob. Kokowski 2015a; 2015b. 
uniwersytetów świata, ${ }^{3}$ a w przypadku ewaluacji nauki polskiej jest to 19.-21. pozycja na świecie. ${ }^{4}$

Mając na względzie tego typu rankingi, minister Barbara Kudrycka w 2010 roku sformułowała następującą tezę:

Ministerstwo chce, by w ciągu 5 lat, [...] co najmniej 5 polskich uczelni znalazło się w pierwszej setce najlepszych placówek w Europie (MNiSW 2010).

Natomiast w 2014 roku premier Donald Tusk, uczestnicząc w posiedzeniu Konferencji Rektorów Akademickich Szkół Polskich w Krakowie, zauważył, że:

ta frustrująco niska pozycja polskich uniwersytetów jest niespójna z pozycją naszej gospodarki w świecie. ${ }^{5}$

Zauważmy, że w tego typu negatywnych ocenach abstrahuje się od podstawowego faktu, że Polska należy do krajów o: a) niskich nakładach na naukę i szkolnictwo wyższe (na świecie 40. pozycja w rankingu Bloomberg Rankings: Most Innovative In The World 2014: Countries), ${ }^{6}$ b) niskiej liczbie pracowników naukowych i naukowo-dydaktycznych przypadającej na milion mieszkańców (37. pozycja w tymże rankingu) ${ }^{7}$ oraz c) bardzo niskich wynagrodzeniach pracowników naukowych i naukowo-dydaktycznych (według prywatnych informacji autora niniejszego artykułu należą one do najniższych w Europie nie tylko w odniesieniu do wynagrodzeń w krajach zachodnich, ale również w stosunku do dawnych krajów bloku socjalistycznego). ${ }^{8}$

Gdy zaś uwzględni się ten fakt, zmienia się całkowicie perspektywa widzenia tej kwestii: przy takich zasadach funkcjonowania nauki i szkolnictwa wyższego 20. pozycja polskiej nauki na świecie w rankingu Scimago Lab "Country Rankings” w 2014 roku budzić powinna duże uznanie.

Jak wiadomo, od początku XXI wieku w Polsce kluczową rolę w ewaluacji instytucji naukowych, periodyków naukowych oraz dorobku naukowego pracowników naukowych

${ }^{3} \mathrm{~Np}$. w rankingach Scimago Lab "SCImago Institutions Rankings” (opartych na bazie Scopus): instytuty PAN w 2009 roku zajęły 65. pozycję (na 3887 ocenianych jednostek), a w 2014 roku - 110. (na 4847 ocenianych jednostek); najlepsze uczelnie zajęły odpowiednio: UJ - 353. i 397. pozycję; UW - 462. i 516; zob. Scimago Lab 2009-2015.

${ }^{4} \mathrm{~Np}$. w rankingach Scimago Lab "Country Rankings" (opartych na bazie Scopus) w 2009 roku Polska zajęła 19. pozycję (na 229 ocenianych krajów), a 2014 roku 20. pozycję (na 229 ocenianych krajów); zob. Scimago Lab 1996-2014.

${ }^{5}$ Cytowane za Gil 2014. Zob. też np. MNiSW 2010; Wprost 2013 („400 najlepszych uczelni na świecie. Tylko jedna z Polski”) i TVN $24 \underline{2015}$ („Ranking najlepszych uniwersytetów na świecie. Polskie uczelnie daleko").

6 Zob. Bloomberg Rankings 2014.

7 Ibidem.

8 Zobacz też: Kokowski 2015a; 2015b (wątek bardzo niskiego finansowania polskiej nauki i szkolnictwa wyższego w kontekście autorskiego modelu uniwersytetu nowego humanizmu); Wróblewski 2013 i Gil 2014. 
odgrywa problem oceny czasopism i monografii naukowych. ${ }^{9}$ Jest to zasadniczo system oceny bibliometrycznej (punktowej), oparty na fundamentalnym założeniu, że najlepsze czasopisma naukowe z każdej dyscypliny znajdują się w bazach Institute for Scientific Information (ISI) w Filadelfii (aktualnie Thomson Reuters). ${ }^{10}$

System ten zdominowany jest przez standardy ewaluacyjne dyscyplin przyrodniczych, preferuje bowiem: a) publikacje w czasopismach kosztem monografiii, ${ }^{11}$ b) publikacje anglojęzyczne ${ }^{12}$ oraz c) popularność publikacji (mierzoną ich cytowalnością), a nie ich jakość. ${ }^{13}$

Deprecjonuje to nauki humanistyczne i społeczne, gdyż często mają one nastawienie lokalne (lokalno-narodowo-państwowe). Podkreślić należy, że taki profil nauk humanistycznych i społecznych ma charakter uniwersalny - dotyczy ogółu krajów i kultur, a nie odnosi się tylko do Polski. ${ }^{14}$ Innymi słowy, lokalność problematyki humanistycznej nie oznacza wcale jej mniejszej wartości. Wiedza tego rodzaju stanowi bowiem wyraz samopoznania jednostki i grupy, budowania własnej tożsamości „tu i teraz”, w „tej, a nie innej wspólnocie”; formułowana jest ona zawsze w określonym języku i w określonym kontekście historyczno-kulturowym. Baza Web of Science zasadniczo nie uwzględnia tej lokalnej problematyki, z oczywistym wyjątkiem kultury kręgu języka angielskiego.

9 To ważny temat dyskusji w ostatnich latach. Zob. np. Kulczycki, Drabek, Falkowska 2012; Woleński 2012; 2013; Wagner 2012a; 2012b; Sorokowski 2012; Lewicka 2013; Drozdowicz 2014; Sadowski, Mach 2014; Kulczycki 2014b; 2015a; 2015b; 2015c; 2015d; Rada Instytutu Filozofii UW 2015.

10 Zob. np. Dryzek 2011; MNiSW 2012b; 2012c; 2013; 2015b; 2015c; Kulczycki 2014b; 2015a; 2015b; 2015c; 2015d. Kwestia, czy są to faktycznie najlepsze czasopisma, omówiona jest poniżej, zob. przyp. 13.

${ }^{11}$ Zdaniem specjalistów tej problematyki to poważny błąd, gdyż monografie są głównym kanałem komunikacji naukowej w naukach humanistycznych i społecznych. Dowiódł to empirycznie m.in. historyk i informatolog Władysław M. Kolasa, w przypadku piśmiennictwa historycznego: „Obliczono, że odsetek książek wśród prac wysoko cytowanych (co najmniej 10 razy) był absolutny i rósł proporcjonalnie do liczby cytowań: $57,91 \%^{(\mathrm{n} \geq 10)}$, $69,57 \%^{(\mathrm{n} \geq 20)}, 80,01 \%^{(\mathrm{n} \geq 30)}, 86,78 \%^{(\mathrm{n} \geq 40)}$ i $93,28 \%^{(\mathrm{n} \geq 50)}$ " (Kolasa $2013 \mathrm{~b}$, ss. $8-9$ ).

12 Zgodnie z ministerialnym rozporządzeniem z 27 października 2015 r., od 1 stycznia 2017 r. język publikacji nie będzie wpływał na punktację publikacji - zob. MNiSW 2015c.

${ }_{13}$ Zwolennicy czasopism uwzględnianych w bazach ISI (aktualnie Thomson Reuters) podnoszą kwestię podobno ich wyższej jakości względem pozostałych czasopism; ma to być skutek rzekomo wyższych standardów recenzowania publikacji $\mathrm{w}$ periodykach zamieszczonych w tych bazach. Gdyby to było prawdą, nie istniałoby m.in. zjawisko anulowania publikacji z czasopism o stosunkowo dużym wskaźniku wpływu - zob. Kokowski 2015j, rozdz. 4.2.7.

${ }^{14}$ Według wspomnianego Władysława M. Kolasy: „Wcześniej na innym materiale (International Bibliography of Historical Sciences) udowodniono tezę, że w historiografii niepodzielnie dominuje język narodowy (Kolasa 2011b), zaś jego udział waha się w przedziale 95,6-98,8\% prac (Francja - 98,8; USA - 98,8; W. Brytania - 98,7; Niemcy - 96,1; Polska 96,0; Rosja - 95,6)” (Kolasa 2013b, s. 8-9). 
Obok takiego braku równouprawnienia nauk, wywołanego deprecjonowaniem nauk humanistycznych i społecznych kosztem nauk przyrodniczych i będącego przejawem problemu dwóch kultur Sartona-Snowa, ${ }^{15} \mathrm{w}$ aktualnym systemie ewaluacji istnieje też nierówność instytucjonalna, gdyż system ten faworyzuje jednostki uniwersyteckie kosztem instytutów PAN. ${ }^{16}$

W tym kontekście narzucają się kluczowe pytania: Jak w ogóle narodziły się w Polsce badania naukometryczne bądź bibliometryczne stosowane w ocenie działalności naukowej? Jak jest to możliwe, że przyjęto w Polsce aż tak dziwny model oceny parametrycznej?

\section{Szkic historii polskich analiz naukometrycznych, opartych na zagranicznych bazach indeksacyjnych}

Od początku lat siedemdziesiątych ubiegłego wieku kompetentne analizy „naukometryczne” i „bibliometryczne" ${ }^{\prime 17}$, odwołujące się do zagranicznych baz indeksacyjnych ${ }^{18}$, podejmowali polscy eksperci wywodzący się ze środowiska bibliotekoznawców. ${ }^{19}$ Jednak

15 Zob. Kokowski 1999; 2001, ss. 54-55, przyp. 47.

${ }^{16}$ Dzieje się tak, gdyż instytuty PAN (choć mają relatywnie największe osiągnięcia naukowe) muszą rywalizować z sobą wzajemnie, a nie ze wszystkimi jednostkami naukowymi danej dziedziny. Zob. Brzeziński 2013; Antonowicz, Brzeziński 2013; Kokowski 2014b.

17 Autorami terminu „наукометрия”, tłumaczonego na język polski jako „naukometria”, są V.V. Nalimov i Z.M. Mulchenko (1967). Natomiast za autora terminu “bibliometrics”, tłumaczonego na język polski jako „bibliometria”, powszechnie uchodzi Alan Pritchard (1969a, 1969b). Jednakże - jak zauważyli Wilson 1995; Hood, Wilson 2001, ss. 292-293 już znacznie wcześniej, bo w 1934 roku, Paul Otlet wprowadził francuski odpowiednik tego terminu "bibliometrie" w rozdziale zatytułowanym "Le Livre et la Mesure. Bibliometrie" w książce Traitée de Documentation. Le livre sur le Livre. Theorie et Pratique, ss. 13-22.

Obok nich, za niemieckim badaczem Otto von Nacke, używany jest także termin „informetria” ("informetrics”) - zob. Nacke, 1979, s. 220; Egghe, Rousseau 1990, ss. V, 1-2.

O genezie i historii naukometrii, bibliometrii oraz informetrii zob. Elkana et al. 1978; Stefaniak 1987, ss. 13-18; Pindlowa 1988; 1990; 1994, ss. 23-34; Skalska-Zlat 1988; 1993; 2001b; Brookes 1988; 1990; Atanasov, Cankova 1990; Sellen 1993; Diodato 1994; Vlachý 1994; Herubel 1999; Shapiro 1999; Hood, Wilson 2001; Glänzel 2004; Van Raan 2004; Garfield 2005, 2006, 2007; Godin 2006; Research Trends 2007a; 2007b; Mingers, Leydesdorff 2015.

O historii pokrewnej dyscypliny, „informacji naukowej”, zob.: Ratajewski 1973; Rayward 1996; Hahn, Buckland 1998; Williams $\underline{2013}$ oraz Aist 2015.

18 Pierwotnie preferowane były bazy Institute for Scientific Information w Filadelfii (założonego przez dra Eugene’a Garfielda w 1960 roku, następnie przejętego w 1992 roku przez prywatną firmę Thomson Scientific \& Healthcare, a od 17 kwietnia 2008 roku przez konsorcjum Thomson Reuters), którym z biegiem czasu nadano zbiorcze nazwy Web of Knowledge, a ostatnio Web of Science. Aktualnie obok baz indeksacyjnych Thomson Reuters coraz większego znaczenia nabiera baza indeksacyjna Scopus firmy Elsevier, rozwijana od 2002 roku.

19 Zob. np. Ratajewski 1973, s. 39-40 (autor ten zwrócił uwagę na fakt, iż coraz częściej wykorzystuje się bazy ISI nie tylko w roli informatora bibliograficznego, ale też podstawy do 
to nie ono odegrało wiodącą rolę w kształtowaniu w Polsce opinii na temat naukometrii i bibliometrii, lecz grono ekspertów związanych z działającym w latach 1991-2005 Komitetem Badań Naukowych.

$\mathrm{U}$ początku swego istnienia KBN skorzystał z pomocy fachowców związanych z seminarium Towarzystwa Popierania i Krzewienia Nauk i uczestników International Workshop: Evaluation of Science and Scientists, zorganizowanego w Pułtusku jesienią 1993, oraz polskich bibliotekoznawców z Instytutu Informacji Naukowej, Technicznej i Ekonomicznej. Ci ostatni wymienieni na zlecenie KBN wykonali zbiór ekspertyz pod zbiorczym tytułem „Wskaźniki udziału polskiego piśmiennictwa naukowego w literaturze światowej”. Dotyczyły one zastosowania naukometrii, bibliometrii oraz baz indeksacyjnych Institute for Scientific Information w Filadelfii do oceny polskiej nauki. ${ }^{20}$ Po tym dopiero przyszły własne opracowania KBN. ${ }^{21}$

Ten typ analiz zapoczątkowała zaś i ugruntowała w Polsce grupa przedstawicieli nauk empirycznych, głównie biologicznych, fizycznych, geologicznych, medycznych oraz biochemicznych, głoszących szerokie spektrum poglądów, m.in.: J. Vetulani (1990), M. Jasieński (1991; 2009); A.K. Wróblewski (1994-2010); G. Racki (1995-2013); A. Pilc (2002a-2012d; 2015); K. Życzkowski i in. (2003-2015); R. Kierzek i in. (2008a-2013c).

W tym ujęciu utożsamiono naukometrię z bibliometrią, badającą cytowania, oraz często zamiennie traktowano terminy „naukometria” i „bibliometria” (co jednak było niezgodne $\mathrm{z}$ intencjami autorów tych pojęć). ${ }^{22}$

Na początku tych analiz - wzorem Eugene’a Garfielda (1979), Alfreda Welljamsa-Dorofa (1993 [1997]), F.H. Herbsteina (1993) - dobrze zdawano sobie jeszcze sprawę z ograniczeń metody cytowań: m.in. z istotnych różnic w cytowaniach w naukach przyrodniczych oraz w naukach społecznych i naukach humanistycznych, wynikających z glo-

badań naukoznawczych); Instytut Informacji Naukowej, Technicznej i Ekonomicznej 1979; Sitarska 1987; Stefaniak 1987; 1994; Pindlowa 1994; Skalska-Zlat 1988; 1993; 2001b; 2002; Ratajewski 1999; Revheim 2002; Drabek 2012, s. 2.

20 Zob. Ziabecki 1994; Stefaniak 1994.

${ }_{21}$ Zob. Kozłowski 1994; Kozłowski, Kopko 1995; Komitet Badań Naukowych, Fundacja Stefana Batorego 1995.

${ }^{22}$ Bowiem według według Vasyla V. Nalimova i Z. M. Mulchenki „naukometria” interesuje się „ilościowymi metodami badania rozwoju nauki jako procesu informacyjnego” (Nalimov, Mulchenko $\underline{1969}, \underline{\text { s. } 2}, \underline{\text { s. }}$ ) ), a według Alana Pitcharda „bibliometria” zajmuje się „zastosowaniem matematycznych i statystycznych metod do książek i innych mediów komunikacji" ["The application of mathematical and statistical methods to books and other media of communication" (Pritchard 1969b, s. 348)]. Co za tym idzie, zakres znaczeniowy naukometrii jest szerszy i obejmuje zakres znaczeniowy bibliometrii. Zob. też: Broadus 1987; Carrizo-Sainero $\underline{2000}$.

Jeszcze szerszy zasięg znaczeniowy ma informetria (“informetrics”), która oznacza „badanie zastosowania metod matematycznych do obiektów informacji naukowej" "“The study of the application of mathematical methods to the objects of information science"; Nacke, 1979, s. 220; Egghe, Rousseau 1990, s. V). 
balnego wymiaru nauk ścisłych, nauk biologicznych oraz nauk medycznych i z lokalnego wymiaru nauk społecznych i humanistycznych, a także z potrzeby stosowania obok oceny bibliometrycznej oceny eksperckiej. ${ }^{23}$ Później jednak - co zobaczymy poniżej - wiedza ta zanikła wśród wielu propagatorów wąsko pojmowanej naukometrii i bibliometrii.

$\mathrm{W}$ analizach tych przyjęto też podstawowe założenie, iż zagraniczne bazy cytowań mają solidne podstawy teoretyczno-empiryczne.

Dla ilustracji tego zagadnienia zacytuję wypowiedź Jana Kozłowskiego:

SCI [Science Citation Index] uwzględnia rocznie ponad 4 tys. czasopism naukowych (oraz kilkaset publikacji książkowych, takich jak prace zbiorowe, monografie), tzn. zaledwie cząstkę światowej produkcji naukowej, Jednakże:

a) rejestruje czasopisma najważniejsze i najbardziej wpływowe;

b) znane prawa „koncentracji dystrybucji” (Bradforda, Lotki, Pareto i Zipfa) mówią m.in., że granice poznania w nauce przesuwają się dzięki publikacjom zamieszczanym w bardzo nielicznych czasopismach. Stwierdzono np., że aż ok. 40\% cytowań powołuje się na prace zamieszczone w 100 czasopismach, a ok. 85\% cytowań odnosi się do publikacji z 1000 czasopism (na kilkadziesiąt tysięcy istniejących (Kozłowski 1994, s. 6). ${ }^{24}$

Inna grupa badaczy - między innymi: R. Tadeusiewicz (1998); J. Wojciechowski (1998, 2000); Z. Żmigrodzki (1998; 1999a; 1999b; 1999c; 1999d; 2000); J. Ratajewski (1999) [w nawiązaniu do takich autorów jak m.in.: C. Daniłowicz, H. Szarski (1979); E. Garfield (1981, 1986)], A. Machalska-Garbacz (1999) - od początku podkreślała na przykład, że: a) te zagraniczne bazy są jedynie bazami bibliometrycznymi (zliczają cytowania), a nie naukometrycznymi (nie mierzą jakości naukowej) i b) są one niereprezentatywne dla części dyscyplin (nauk technicznych, nauk o kulturze fizycznej, bibliologii, bibliotekoznawstwa itp.). Ale tezy te nie znalazły posłuchu, choć podobne głosili później między innymi: W. Petryński (2008) i A. Sawicki (2013a, 2013b).

${ }^{23}$ Zob. Stefaniak 1994, ss. 61-63; Kozłowski 1994, ss. 7-9; Kozłowski, Kopka 1995, s. 4.

${ }^{24}$ Inni przedstawiciele tej grupy, o ile mi wiadomo, tylko $\mathrm{z}$ wyjątkiem historyka i informatologa Piotra Nowaka 2008, jeśli w ogóle podejmowali ten wątek w swoich publikacjach, czynili to tylko zdawkowo, powołując się bądź na autorytet Eugene’a Garfielda, twórcy baz danych ISI, bądź też na uznanie, jakim darzone były te bazy w środowisku badaczy nauk empirycznych. Zwracam tu uwagę na wczesną publikację Andrzeja Kajetana Wróblewskiego z 1998 roku, w której pojawiają się następujące stwierdzenia: „Wymienione bazy danych [Science Citation Index (SCI) oraz uzupełnienia: Social Science Citation Index (SSCI) i Arts \& Humanities Citation Index (AHCI)] są tworzone na podstawie monitorowania najważniejszych czasopism naukowych. Lista czasopism została ustalona tak, aby zgodnie z tzw. prawem Bradforda obejmować ogromną większość wszystkich cytowań na świecie" (Wróblewski 1998a). W późniejszej publikacji - zob. Wróblewski $\underline{2013}$ - wymienił on, obok prawa Bradforda, również prawo Lotki i prawo Bradforda-Garfielda. (Trzeba jednak jednoznacznie zaznaczyć, że autor ten ma wielkie zasługi w krytykowaniu nieodpowiedzialnego stosowania baz cytowań w ocenianiu badań naukowych - zob. Wróblewski 1994 - 2015b.) 
Po likwidacji KBN podejście naukometryczne nabierało coraz większego znaczenia w kolejnych instytucjach zarządzających polską nauką. ${ }^{25}$ Stąd właśnie wynika aktualna konieczność wykazywania się przez pracowników naukowych (niezależnie od dziedziny wiedzy) indeksami Hirscha swoich publikacji, cytowaniami w bazach Web of Science czy Scopus itp., bez konieczności weryfikowania tych cytowań przez ekspertów.

\section{Aktualna dyskusja na temat naukometrii i bibliometrii w Polsce}

Ostatnią odsłoną dyskusji z zakresu naukometrii / bibliometrii są teksty opublikowane na łamach PAUzy Akademickiej przez dwie grupy badaczy, do których należą: a) A. Pilc (2011-2012, 2015a) i A. Proń, M. Kosmulski (2015a; 2015b) - głoszący pochwałę naukometrii, J. Zakrzewski i K. Życzkowski (2014-2015) - postulujący zastąpienie Impact Factor (IF) czasopism przez wskaźnik Article Influence Score (AIS), powiązany z algorytmem Eigenfactor oraz A.K. Wróblewski (2015a, 2015b) - krytykujący pomysł J. Zakrzewskiego i K. Życzkowskiego zgodnie z przekonaniem, że o wartości publikacji decyduje jej wartość merytoryczna, a nie liczbowe wskaźniki i b) A. Proń i H. Szatyłowicz (2012) i A. Płaźnik (2015) - krytykujący tezy A. Pilca i opowiadający się przeciwko utożsamieniu bibliometrii z naukometrią, oraz Z. Błocki i K. Życzkowski 2012 - podzielający takie rozumienie bibliometrii, a także L. Sokołowski (2015), W. Korohoda (2015) oraz P. Domański (2015) (ten ostatni nawiązuje do publikacji trzech autorów: P. O. Selena (1997), D. N. Arnolda (2009) oraz D. N. Arnolda, K. K. Fowlera (2010)) - którzy zdecydowanie negują wartość naukometrii, uznając skutki jej stosowania za szkodliwe dla rozwoju nauki.

Pierwszy krąg badaczy - mimo różnic w poglądach - jest przekonany, iż „oczywiście duża liczba cytowań czy wysoki współczynnik h wskazują z dużym prawdopodobieństwem, że dany autor zrobił w nauce coś istotnego" (Wróblewski 2015b). ${ }^{26}$

Teza ta na pierwszy rzut oka wydaje się trafna w przypadku działalności naukowej z zakresu rozwiniętych nauk empirycznych, takich jak nauki medyczne, fizyczne, chemiczne oraz ekonomiczne. ${ }^{27}$ Dyscypliny te bowiem są uprawiane przez duże społeczności naukowców oraz są one od lat hojnie finansowane na świecie - posiadają więc rozwiniętą infrastrukturę bibliometrycznych baz indeksacyjnych (Web of Science, Scopus, ...), skupionych na analizie cytowań wyselekcjonowanych czasopism naukowych (wymienionych w Journal Citations Reports (Thomson Reuters) i Scopus Journal List).

${ }^{25}$ Tzn. w Ministerstwie Nauki i Informatyzacji (2.05.2004-31.10.2005), Ministerstwie Nauki i Edukacji (31.10.2005-5.05.2006), Ministerstwie Nauki i Szkolnictwa Wyższego (od 5.05.2006), Narodowym Centrum Badań i Rozwoju (od lata 2007, a na nowych zasadach od 30.04.2010) oraz Narodowym Centrum Nauki (od 4.03.2011).

26 Zob. też Kuś, Mankiewicz, Życzkowski 2009, s. 33; Błocki, Życzkowski 2012, s. 2, p. 12.

${ }^{27}$ Najsilniej przemawiają za tym predykcje w latach 2002-2014: aż 35 ze 101 laureatów nagród Nobla w dziedzinie fizyki, chemii, fizjologii lub medycyny oraz ekonomii (D. Pendlebury, analityk cytowań z Thomson Reuters) - zob. Thomson Reuters Science Watch 2015; Nobelprize.org. The Official Web Site of the Nobel Prize 2015. 
Jednak druga grupa autorów neguje pogląd, jakoby istniał konieczny związek między dużą wartością indeksu Hirscha a jakością naukową publikacji. Jak jasno bowiem pokazali A. Proń i H. Szatyłowicz (2012), wartości indeksów Hirscha silnie zależą od liczby naukowców zajmujących się badaniami (im jest ona większa, tym większa jest liczba potencjalnych cytowań). Na mocy tego typu analiz A. Proń i H. Szatyłowicz formułują następujące kluczowe uogólnienie:

W analizach dorobku naukowego żadne wskaźniki bibliometryczne nie zastąpią uważnego przeczytania co najmniej 10 reprezentatywnych publikacji ocenianego kandydata. ${ }^{28}$

Idąc tropem takich rozważań, Z. Błocki, K. Życzkowski (2012, s. 2, punkt 13; 2013, ss. 38-42) przedstawili empiryczne dowody, że na gruncie fizyki, a tym bardziej matematyki, nie istnieje korelacja między dużą wartości indeksu Hirscha naukowca, a zdobyciem nagrody Nobla w dziedzinie fizyki i medalu Fieldsa w matematyce.

Mając na względzie tego typu kwestie, M. Kosmulski i A. Proń (2014) uznali wskaźnik Hirscha za miernik popularności publikacji, a nie jej wartości naukowej.

Z kolei W. Korohoda (2015), nawiązując do rozważań C. Bartnecka, S. Kokkelnansa (2011), zwrócił uwagę na istnienie bardzo groźnego zjawiska, obejmujące środowisko naukowe. Jest nim mechanizm manipulowania wartościami wskaźników naukometrycznych (liczby cytowań, IF, h-index), wywołany głównie przez rozpowszechnienie się patologicznej formy organizacji badań naukowych. Polega ona na dopisywaniu się do publikacji ważnych socjologicznie postaci (np. dziekanów, profesorów itp.), osób które nie wniosły żadnego wkładu w badania. Poparł ten punkt widzenia P. Domański (2015), przypominając wcześniejsze publikacje P.O. Selena (1997), D. N. Arnolda (2009) oraz D.N. Arnolda, K.K. Fowlera (2010).

Reasumując: Konsekwencją zróżnicowania środowiska naukowego i poszczególnych dziedzin nauki oraz braku dialogu międzydyscyplinarnego (będącego przejawem opozycji dwóch kultur Sartona-Snowa) jest ogromny rozrzut opinii na temat przydatności metod naukometrycznych czy bibliometrycznych w ocenie dorobku naukowego.

\section{Niewystarczające uzasadnienie stosowania metod naukometryczych}

Mimo wspomnianych w poprzednich rozdziałach tego artykułu krytyk metody naukometrycznej, jest ona od lat konsekwentnie stosowana w Polsce do oceny zarówno czasopism naukowych, jak i instytucji naukowych oraz samych naukowców.

${ }^{28}$ Dodam tu na marginesie, że twierdzenie to nie ma wcale oryginalnego charakteru i podziela je wielu uczonych. Głosił je np. już wcześniej Richard R. Ernst (2010), laureat Nagrody Nobla z chemii w 1991 roku za rozwój metody badań za pomocą wysokorozdzielczego magnetycznego rezonansu jądrowego (NMR): „Zacznij czytać artykuły, zamiast jedynie oceniać je przez zliczanie cytowań!"("Start reading papers instead of merely rating them by counting citations!"). 
Możliwą obroną takiego zwyczaju jest przyjęcie hipotezy, że naukometryczne analizy mają jednak solidne podstawy naukowe, a głos krytyków jest wyrazem ich niekompetencji. Można też przyjąć nieco odmienną strategię i stwierdzić łagodniej, że głosy krytyków nie przeważyły jednak głosów zwolenników naukometrii.

Taka obrona jest jednak ułomna i mało skuteczna, co wynika z przeoczenia poważnego błędu z zakresu wiedzy historycznej, który zostanie wskazany w poniższym rozdziale.

\section{Elementarny błąd dotychczasowych analiz „naukometrycznych”}

Zdecydowana większość znanych autorowi tego artykułu analiz „naukometrycznych” (tak krajowych, jak i zagranicznych) $\mathrm{z}$ ostatnich dekad obarczona jest elementarnym błędem, polegającym na tym, że dokonuje się ich w oderwaniu od wiedzy naukoznawczej, a konkluzje takich analiz dotyczą właśnie takiej wiedzy.

Gdy dochodzi do tego typu zerwania więzi dyscyplinarnych, naukometria oferuje zbyt uproszczone wizje oceny i rozwoju nauki, widzianej przez pryzmat prostych wskaźników liczbowych. W szczególności postuluje się błędny pomysł strukturalnego deprecjonowania specyficznych polskich dyscyplin humanistycznych (filologii polskiej, historii Polski, historii nauki polskiej) poprzez preferowanie: a) artykułów kosztem monografii (poprzez nadanie tym pierwszym wyższej punktacji) i b) czasopism wymienianych w bazach Thomson Reuters (a także w pewnym stopniu w bazie Scopus, a nawet nieistniejącej już bazie ERIH) względem czasopism krajowych nieuwzględnianych w tych bazach. ${ }^{29}$

W tym kontekście należy przypomnieć (to truizm dla nielicznych w Polsce naukoznawców, ale niestety nadal niemal wiedza ezoteryczna dla pozostałej grupy badaczy), iż w skład naukoznawstwa wchodzą między innymi: historia nauki, filozofia nauki, socjologia wiedzy naukowej, teoria organizacji nauki, psychologia odkrycia naukowego, ekonomika nauki, polityka nauki oraz naukometria (i bibliometria). Do naukoznawstwa zaliczyć też trzeba stosunkowo nową specjalizację naukową określaną mianem komunikacji naukowej, która odgrywa kluczową rolę w tworzeniu teorii cytowania i oceny cytowań publikacji naukowych. ${ }^{30}$

Z badań historycznych (źródłowych i literaturowych) wiemy, że: a) taki właśnie związek między naukoznawstwem i naukometrią leżał u podstaw naukometrii u jej początków i b) był on owocem polskiego naukoznawstwa zarówno przedwojennego, jak i powojennego oraz międzynarodowej współpracy na tym polu w latach 60. i 70. XX wieku ${ }^{31}$ oraz

${ }^{29}$ Zob.: Kokowski 2014a;2014b. Kwestia bazy ERIH zostanie wyjaśniona w rozdziale 8.

30 To połączenie: scholarly communications, science communication oraz scientific communication. Zob. Meadows 1974; Konieczna 1982; Zuccala 2006; Stefaniak 2009; Romary 2011; Kulczycki 2012; The Wellcome Trust 2015; UNESCO 2015 oraz Haustein, Sugimoto, Larivière 2015 (o roli altmetrics, czyli alternatywnych miar, w komunikacji naukowej).

31 Był to aksjomat ówczesnych naukometrów zarówno z krajów socjalistycznych, jak i zachodnich. Zob. De Solla Price 1963/1967a; Nalimov, Mulchenko 1969, ss. 5-10; Dobrov 1969; Beck, Dobrov, Garfield, de Solla Price 1978; Necke 1979; Krauze, Kowalewski, Pod- 
c) świadomość tych faktów była i jest nadal obecna w środowisku polskich bibliotekoznawców. $^{32}$

Z analizy licznych publikacji, których autorami są propagatorzy naukometrii, wynika też jednoznaczny wniosek: nie zdają oni sobie sprawy, że naukoznawstwo (jako dyscyplina akademicka) powstało nie gdzie indziej, lecz w Polsce, w latach 1910-1920 za sprawą działalności szkoły lwowsko-warszawskiej i Kasy im. Józefa Mianowskiego. Polscy zwolennicy tak rozumianej naukometrii nie widzą też związku między upadkiem organizacyjnym naukoznawstwa w czasach wolnej Polski (po 1989 roku), gdy rozwiązano instytucje zajmujące się takimi badaniami i nie powołano w ich miejsce żadnych nowych, ${ }^{33}$ a faktem wzmagającego się organizacyjnego niedowładu polskiej nauki i szkolnictwa wyższego w ostatnich latach (czyli w czasach rewolucyjnych zmian tych sfer życia społecznego w wyniku działań zainicjowanych przez minister Barbarę Kudrycką).

Indolencja ta jest zaś efektem narastającego centralizmu i zbiurokratyzowania oraz marginalizacji polityki naukowej, nasilającego się technokratyzmu dużej części polskich naukowców oraz istnienia bardzo silnego lobbingu korporacji uniwersyteckich. Istnieje wiele przejawów tego złożonego zjawiska, wymieńmy niektóre z nich:

a) fakt, iż nauka i szkolnictwo wyższe od wielu już lat nie należą do priorytetów politycznych w naszym kraju (doskonałym tego miernikiem są nakłady mierzone w procentach PKB - jedne z niższych w Europie i na świecie); ${ }^{34}$

b) oparcie polityki naukowej (oceny dorobku naukowego i czasopism, finansowania jednostek naukowych) na wąsko pojmowanej naukometrii, wyrwanej z kontekstu naukoznawstwa; ${ }^{35}$

c) brak systemowych mechanizmów wspierających rozwój instytutów PAN, mimo iż od lat należą one do najbardziej wydajnych jednostek naukowych w Polsce; ${ }^{36}$

górecki 1977; Haitun 1980, s. 65; Merton, Garfield, 1987, pp. 73-74; Dagite, Voverena 1990; Wouters 1999; Garfield 2007; Kinouchi 2014.

32 Zob. np.: Sitarska 1987; Stefaniak 1987, s. 16; 1994, s. 49; Pindlowa 1988, ss. 307-309; 1990, s. 69; 1994, s. 15; Skalska-Zlat 1988, ss. 279-282; 2001a; 2002; Ratajewski 1993; $\underline{1999}$; Kolasa 2013a, s. 5.

${ }_{33}$ Zob. dwie obszerne publikacje na ten temat: Kokowski 2015g (w druku), 2015h.

34 Zob. Kokowski 2015h.

${ }^{35} \mathrm{Na}$ początku omawianego rozdziału wyjaśniono, na czym polega jej nieprawidłowość. Skutkiem tego błędu przyjęto wadliwy mechanizm wyboru członków Komitetu Ewaluacji Jednostek Naukowych i ministerialnego zespołu ds. oceny czasopism naukowych. Jak się bowiem okazuje - zob. MNiSW 2012a; 2015a; Kulczycki 2014a - grupy te są zdominowane przez pracowników, którzy w swojej karierze zawodowej nie analizowali problematyki naukoznawczej, a taką właśnie zajmują się te grona, formułując zasady ocen naukometrycznych, które mają bezpośredni wpływ na mechanizm finansowania działalności naukowej jednostek naukowych.

36 O dorobku tych instytutów świadczą jednoznacznie wyniki ewaluacji polskich jednostek naukowych przeprowadzonych zarówno przez MNiSW (2010b; 2014a; 2014b), jak i przez Scimago Lab (2009-2015). Por. powyżej przyp. 3 i Kokowski 2015b, s. 31. 
d) brak mechanizmu minimalnych wynagrodzeń i ich wzrostu w instytutach PAN w odróżnieniu od szkół wyższych (prowadzi to do sytuacji, gdy część bardzo dobrych instytutów PAN wypłaca znacznie niższe wynagrodzenia niż nawet najsłabsze jednostki uniwersyteckie); ${ }^{37}$

e) dokonywanie nieustannych modyfikacji kluczowych regulacji prawnych, na przykład zasad oceny czasopism naukowych, bez wprowadzania odpowiednio długiego vacatio legis.

\section{Kluczowy postulat}

Mając na względzie: a) polski model oceny dorobku instytucji naukowych, czasopism oraz badaczy, b) historię polskich analiz naukometrycznych, opartych na zagranicznych bazach indeksacyjnych oraz c) aktualną dyskusję na temat naukometrii i bibliometrii w Polsce, autor niniejszego artykułu postuluje powrót do badań informetrycznych (naukometrycznych, bibliometrycznych, webometrycznych, ...), świadomie rozwijanych $w$ kontekście zintegrowanego naukoznawstwa. W pełni bowiem podziela on w tej kwestii opinię bibliotekoznawcy Jerzego Ratajewskiego, sformułowaną w 1999 roku:

Naukoznawcy z wielu krajów uważają, że do oceny wartości nauki i uczonych należy stosować nie tylko badania ilościowe (statystyczne), ale cały kompleks metod i technik badawczych wypracowanych przez różne dziedziny i dyscypliny nauki. ${ }^{38}$

Co więcej, takie odrodzenie w Polsce zintegrowanych badań naukoznawczych zaowocuje z jednej strony pogłębioną analizą metod informetrycznych, wolną od wielu uproszczeń, które aktualnie rządzą polskim systemem oceny dorobku naukowego, a $\mathrm{z}$ drugiej - intensyfikacją rozwoju bazy informetrycznej (w szczególności repozytoriów cyfrowych otwartego dostępu). ${ }^{39}$ Byłby to fundament nowej, zintegrowanej polityki naukowej, która z równym szacunkiem odnosiłaby się do dokonań: a) ogółu nauk, nie wszczynając wojen między dwoma kulturami (w sensie Sartona-Snowa) i b) zarówno jednostek uniwersyteckich, jak i jednostek pozauniwersyteckich (w tym instytutów PAN).

${ }^{37}$ Por. art. 151 ust. 1 pkt 1 ustawy z dnia 27 lipca 2005 r. - Prawo o szkolnictwie wyższym (Dz.U. nr 164 poz. 1365, z późn. zm.) i art. 104 i 105 ustawy z dnia 30 kwietnia 2010 r. o Polskiej Akademii Nauk (Dz.U. Nr 96, poz. 619). Ujednolicenie tych zapisów postuluje od lat Krajowa Sekcja NSZZ „Solidarność” PAN i Inicjatywa Obywatelska Instytutów PAN (2012).

Wymowę tego faktu potęguje jeszcze to, że aż 43\% nauczycieli akademickich w Polsce praktycznie w ogóle nie publikuje - zob. Kwiek 2014, s. 15.

38 Ratajewski 1999. Zdaniem tego autora „na słuszność tej tezy wskazała międzynarodowa dyskusja nad tzw. «Hipotezą Ortegi» przeprowadzona na łamach Scientometrics w 1987 r.”. W odróżnieniu od niego autor niniejszego artykułu uważa, że przemawia za tym wiele innych argumentów; zostanie to okazane w innym artykule - zob. Kokowski 2015j.

39 Zob. Kokowski 2014a; 2015c. 


\section{8. „Praktyczna lekcja z historii naukoznawstwa” i aktualna polityka naukowa}

Na zakończenie tego artykułu warto odnieść wiedzę z historii polskiego naukoznawstwa do aktualnego problemu, jakim jest kształtowanie polityki naukowej w Polsce.

W tym kontekście zasadne będzie postawienie fundamentalnych pytań problemowych dotyczących struktury organizacyjnej polskiej nauki: Jaki wybrać w Polsce model uniwersytetu? ${ }^{40}$ Jaką rolę w systemie polskiej nauki powinny pełnić: a) instytuty badawcze, w tym instytuty PAN, oraz b) akademie i towarzystwa naukowe? Jaki wybrać model oceny dokonań naukowych zarówno instytucji, jak i pracowników? Jaki przyjąć system oceny czasopism naukowych?

Można też sformułować szczegółowe pytania dotyczące przyszłego schematu oceny czasopism (w 2017 roku):

1) Jaką bazę wybrać za podstawę listy czasopism A? Czy Journal Citation Reports z Web of Science, czy jednak bazę Scopus? Przecież ta druga jest zarówno bardziej liczna i różnorodna, jak i bardziej reprezentatywna pod względem geograficznym i językowym. Co więcej, w przeciwieństwie do WoS, Scopus wyznacza wskaźniki wpływu na naukę dla prawie każdego indeksowanego czasopisma i są one - zdaniem bibliometrów - określone bardziej profesjonalnie niż impact factor (IF) firmy Thomson Reuters. Scopus wylicza dwa główne wskaźniki: SCImago Journal Rank (SJR) - oparty na liczbie cytowań artykułów opublikowanych w danym czasopiśmie z uwzględnieniem naukowego prestiżu źródeł cytujących i Source Normalized Impact per Paper (SNIP) - uwzględniający liczbę cytowań artykułów opublikowanych w danym źródle w odniesieniu do całkowitej liczby cytowań w danym obszarze tematycznym. ${ }^{41}$

2) Czy za podstawę listy czasopism $\mathrm{C}$ wolno wybrać nieistniejący już $\mathrm{ERIH}^{42}$, czy może ERIH PLUS $?^{43}$ Innymi słowy: Czy premiowanie czasopism wymienianych w ERIH (chodzi o co najmniej 10 pkt. - zob. MNiSW 2015b, $\$ 5.1-2$ ), a niepremiowanie

${ }^{40}$ Autor niniejszego artykułu zabrał już głos w tej dyskusji - zob. Kokowski 2015a (tekst referatu wygłoszonego podczas Kongresu Kultury Akademickiej „Idea Uniwersytetu Reaktywacja” w Krakowie 20 marca 2014 r.); 2015b (rozwinięta postać tego referatu).

${ }^{41}$ Za wyborem bazy Scopus opowiada się np. Zbigniew Osiński (2013c; 2014b). Autor niniejszego artykułu podziela ten punkt widzenia.

${ }^{42}$ Należy podkreślić, że w sensie prawnym baza ERIH (zawierającą czasopisma humanistyczne) przestała istnieć w styczniu 2014 roku. Została ona wtedy przekształcona w bazę ERIH PLUS (zawierającą czasopisma humanistyczne i społeczne), w której zostały zamieszczone na równych prawach czasopisma dawnego ERIH oraz te, które złożyły podania o włączenie do nowej bazy po zamknięciu ERIH. Zob. European Science Foundation 2014.

${ }^{43} \mathrm{Na}$ marginesie warto przypomnieć, że dobór czasopism bazy ERIH i ich ocena były bardzo krytykowane przez międzynarodową społeczność naukową. O negatywnych opiniach na temat oceniania czasopism z zakresu historii nauki - zob. np. Cook et al. 2009. 
w ten sam sposób czasopism ERIH PLUS nieuwzględnionych wcześniej w ERIH nie jest prawnym błędem, dyskryminującym nowe czasopisma ERIH PLUS? ${ }^{44}$

3) Czy jest uzasadnione, by w naukach humanistycznych i społecznych punktacja za monografie naukowe musiała być niższa niż za artykuły? Jeśli tak, doprowadzi to do zaniku publikowania monografii, a ta forma uznawana jest przez specjalistów za główną formę komunikacji naukowej w tych dziedzinach. ${ }^{45}$

4) Czy można dopuścić sytuację, by rodzime czasopismo - choć nieobecne w bazie WoS czy Scopus - z zakresu polskiej specjalizacji naukowej, w której nasza nauka jest liderem światowym, miało prawo otrzymać najwyższą punktację (aktualnie 50 pkt)? Jeśli nie, nastąpi proces stopniowej marginalizacji takich specjalizacji, co działałoby na szkodę polskiej kultury i byłoby niewątpliwie sprzeczne z polską racją stanu (i konstytucją). ${ }^{46}$

Na tego typu pytania nie można odpowiedzieć merytorycznie bez rzetelnej wiedzy z zakresu naukoznawstwa i jego historii, o czym niestety zapominano w Polsce w ostatnich dekadach.

\section{Podziękowania}

Autor artykułu składa podziękowania Recenzentom za ich kompetentne komentarze, które przyczyniły się do pogłębienia publikacji.

\section{BIBLIOGRAFIA}

Uwaga:

Odnośniki dotyczące literatury z zakresu naukometrii - bibliometrii - informetrii, zob. Kokowski 2015.

AGUILLO Isidro, BAR-ILAN Judit, LEVENE Mark, ORTEGA José

2010: Comparing university rankings. Scientometrics 85(1), pp. 243-256. DOI: 10.1007/s11192-010-0190-z. Available online: http://www.akademiai.com/doi/ abs/10.1007/s11192-010-0190-z.

${ }^{44} \mathrm{~W}$ trakcie prac ministerialnego zespołu do spraw czasopism pojawił się pierwotnie pomysł, by po zamknięciu w 2014 roku ERIH, pominąć tę listę, jak i jej kontynuację ERIH PLUS, a zastąpić ją przez SCOPUS - zob. Kulczycki 2015a. Autor niniejszego artykułu - zob. Kokowski 2015c (w ramach „Głosu w dyskusji” z dnia 14 marca 2015) - skrytykował ten pomysł jako niespójny z wcześniejszą polityką MNiSW, zgodnie z którą polecano redakcjom czasopism, aby podejmowały starania o włączenie do listy ERIH PLUS. Ostatecznie jednak przyjęto zaskakujący pomysł dowartościowania tylko czasopism dawnego ERIH.

${ }^{45}$ Zob. Kokowski 2014a.

${ }^{46}$ Ibidem. 
BASTOW Simon, DUNLEAVY Patrick, TINKLER Jane

2014: The Impact of the Social Sciences: How Academics and their Research Make a Difference. Sage. ISBN 978-4462-7509-2. Available online: http://uk.sagepub.com/ sites/default/files/upm-binaries/59598 Bastow Impact of the social sciences. pdf.

\section{BLOOMBERG RANKINGS}

2014: Most Innovative In The World 2014: Countries. Available online: http://images.businessweek.com/bloomberg/pdfs/most innovative countries 2014 011714.pdf.

CAMERON William Bruce

1963: Informal Sociology: A Casual Introduction to Sociological Thinking. New York: Random House. Available online: https://books.google.pl/books/about/Informal sociology.html?id=I6JIAAAAMAAJ.

CENTER FOR WORLD-CLASS UNIVERSITIES OF SHANGHAI JIAO TONG UNIVERSITY (CWCU)

2015: Academic Ranking of World Universities. Available online: http://www.shanghairanking.com/.

CENTRE FOR SCIENCE AND TECHNOLOGY STUDIES, LEIDEN UNIVERSITY

2015: CWTS Leiden Ranking. Available online: http://www.leidenranking.com.

CIEŚLIŃSKI Piotr

2012: Polska w naukowym ogonie Europy - tylko jeden grant na 536! Gazeta Wyborcza 11 września 2012 r., s. 1. Publikacja dostępna w Internecie: http:// wyborcza.pl/1,76842,12461333,Polska w naukowym ogonie Europy tylko jeden grant.html\#ixzz3vRSoMeQ6.

CYBERMETRICS LAB (CCHS), A UNIT OF THE SPANISH NATIONAL RESEARCH COUNCIL (CSIC)

2015: Ranking Web of World Universities. Available online: http://www.webometrics. info/.

DRYZEK Helena

2011: Punktacja za publikacje [w latach 2001-2011]. Publikacja dostępna w Internecie: http://www.mini.pw.edu.pl/ dryzek/www/?S\%B3ownik:Punktacja za publikacje.

HIGHER EDUCATION EVALUATION AND ACCREDITATION COUNCIL OF TAIWAN

2015: Performance Ranking of Scientific Papers for World Universities. Available online: http://ranking.heeact.edu.tw/.

JACKOWSKI Stefan, KRAWCZYK Magdalena, OPALA Paweł

2010: Jak świat widzi polskie uczelnie? 02/2010. Publikacja dostępna w Internecie: https://forumakademickie.pl/fa/2010/02/jak-swiat-widzi-polskie-uczelnie/. 
KOKOWSKI Michał

2001: Thomas S. Kuhn (1922-1996) a zagadnienie rewolucji kopernikowskiej. Warszawa: Wydawnictwa IHN PAN. ISBN 83-86062-02-9. Publikacja dostępna w Internecie: Kujawsko-Pomorska Biblioteka Cyfrowa; http://kpbc.umk.pl/dlibra/ doccontent?id=41760.

2015: Bibliografia naukometryczno-bibliometryczno-informetryczna. Wybór. Prace Komisji Historii Nauki PAU 14, ss. 183-264. Publikacja dostępna w Internecie: http://pau.krakow.pl/PKHN-PAU/pkhn-pau-XIV-2015-9.pdf.

KRAJOWA SEKCJA NSZZ „SOLIDARNOŚĆ” PAN, INICJATYWA OBYWATELSKA INSTYTUTÓW PAN

2012: Projekt nowelizacji ustawy o PAN. Publikacja dostępna w Internecie: http://www. ioi.pan.pl/nowelizacja.

KWIEK Marek

2014: Internationalization and Research Productivity: "Internationalists" and "Locals" in Polish Universities. The Higher Education in Russia and Beyond 2, Fall 2014, pp. 13-15. Available online: http://www.cpp.amu.edu.pl/kwiek/pdf/Kwiek HERB Fall_2014.pdf.

2015: Uniwersytet $w$ dobie przemian. Instytucje i kadra akademicka $w$ warunkach rosnacej konkurencji. Warszawa; Wydawnictwo Naukowe PWN.

LEWICKI Jacek

2015: Polskie uczelnie w rankingach. Wszystko co najważniejsze. Publikacja dostępna w Internecie: https://wszystkoconajwazniejsze.pl/jacek-lewicki-polskie-uczelnie-w-rankingach/.

LIMPERT Eckhard, STAHEL Werner A., ABBT Markus

2001: Log-normal Distributions across the Sciences: Keys and Clues. BioScience 51(5) (May 2001), pp. 341-352. Available online: DOI: http://dx.doi.org/10.1641/0006-3568(2001)051[0341:LNDATS]2.0.CO;2. http://stat.ethz.ch/ stahel/lognormal/ bioscience.pdf.

\section{MOJASOCJOLOGIA.PL}

2014: Metoda biograficzna. [W:] Portal „MojaSocjologia.pl”. Publikacja dostępna w Internecie: http://www.mojasocjologia.pl/metoda-biograficzna/.

O’TOOLE Garson

2010: Not Everything That Counts Can Be Counted. The Quote Investigator. Exploring the Origins of Quotations. May 26, 2010. Available online: http://quoteinvestigator. com/2010/05/26/everything-counts-einstein/.

\section{QS QUACQUARELLI SYMONDS LIMITED}

2015: QS World University Rankings. Available online: http://www.topuniversities.com/ university-rankings/. 


\section{SCIMAGO LAB}

2009-2015: Scimago Institutions Ranking. Available online: http://www.scimagoir.com. 1996-2014: Country Rankings. Available online: http://www.scimagojr.com/countryrank. php.

\section{TIMES HIGHER EDUCATION}

2015: The World University Rankings. Available online: http://www.timeshighereducation.co.uk/world-university-rankings/.

TVN 24

2015: Ranking najlepszych uniwersytetów na świecie. Polskie uczelnie daleko. TVN 24 16.09.2015. Publikacja dostępna w Internecie: http://tvn24bis.pl/ze-swiata,75/ ranking-najlepszych-uniwersytetow-na-swiecie, 577690.html.

WOLFF Stefan L.

2003: Physicists in the "Krieg der Geister": Wilhelm Wien's "Proclamation". Historical Studies in the Physical and Biological Sciences 33, No. 2 (2003), pp. 337-368. Available online: http://www.jstor.org/stable/10.1525/hsps.2003.33.2.337. The earlier German version: Physiker im "Krieg der Geister" (Arbeits Papier/ Working Paper); http://www.mzwtg.mwn.de/arbeitspapiere/Wolff 01.pdf.

\section{WPROST}

2013: 400 najlepszych uczelni na świecie. Tylko jedna z Polski. Wprost 4.10.2013. Publikacja dostępna w Internecie: http://www.wprost.pl/ar/419453/400-najlepszych-uczelni-na-swiecie-Tylko-jedna-z-Polski/.

ZENDEROWSKI Radosław

2008: Plagiat. Istota - rodzaje - skutki ( $w$ odniesieniu do prac pisemnych na studiach wyższych). Warszawa: Instytut Politologii Uniwersytet Kard. Stefana Wyszyńskiego w Warszawie. Publikacja dostępna w Internecie: http://www.zenderowski.republika.pl/plagiat.pdf (29.11.2014). 


\title{
A SKETCH ON THE CURRENT DEBATE ON SCIENTOMETRICS AND BIBLIOMETRICS VERSUS THE FORGOTTEN SCIENCE OF SCIENCE
}

\begin{abstract}
In the debate on scientometrics and bibliometrics, taking place in Poland in the last 25 years, a very serious methodical and methodological mistake has been committed by neglecting the reflection about the science of science, especially of historical and methodological character. The following article discusses this issue.

This aim was achieved with the use of a method of interdisciplinary research originating from the scope of the science of science and the history of the science of science. This method was applied to the analysis of selected major publications on scientometrics and bibliometrics in the past 25 years, with special emphasis on Polish context.

The results are discussed in the article, i.e. a) the context of the current debate on scientometrics and bibliometrics in Poland; b) the history of Polish scientometric analyses based on foreign indexation databases; c) the current discussion on scientometrics and bibliometrics in Poland and d) the key aspect ignored in the current debate, namely the inseparable connection of scientometrics and bibliometrics with the science of science.

The study leads to the following conclusions: it is postulated that the informetric (scientometric, bibliometric, Webometric, etc.) studies return to the scientific discourse, which would be consciously developed in the context of the integrated science of science. This knowledge should be utilized in the development of the current science policy, i.e. the organizational structure of science and higher education and the formation of rules of appraisal of scientific institutions, individual employees and scientific journals.
\end{abstract}

Keywords: scientometrics, bibliometrics, informetrics, methodology of scientometrics, abuses of scientometric methods, science of science, science policy, Polish and international context 